\title{
Clinical and mutational profiles of adult medulloblastoma groups
}

Gabriel Chun-Hei Wong ${ }^{1 *+}$ (0), Kay Ka-Wai Li ${ }^{1 \dagger}$, Wei-Wei Wang ${ }^{2+}$, Anthony Pak-Yin Liư ${ }^{3}$, Queenie Junqi Huang ${ }^{1}$, Aden Ka-Yin Chan', Manix Fung-Man Poon ${ }^{1}$, Nellie Yuk-Fei Chung ${ }^{1}$, Queenie Hoi-Wing Wong ${ }^{1}$, Hong Chen ${ }^{4}$, Danny Tat Ming Chan ${ }^{5}$, Xian-Zhi Liu ${ }^{6}$, Ying Mao ${ }^{7 *}$, Zhen-Yu Zhang ${ }^{6 *}$, Zhi-Feng Shi ${ }^{7 *}$ and Ho-Keung Ng ${ }^{1}$

\begin{abstract}
Adult medulloblastomas are clinically and molecularly understudied due to their rarity. We performed molecular grouping, targeted sequencing, and TERT promoter Sanger sequencing on a cohort of 99 adult medulloblastomas. SHH made up 50\% of the cohort, whereas Group 3 (13\%) was present in comparable proportion to WNT (19\%) and Group 4 (18\%). In contrast to paediatric medulloblastomas, molecular groups had no prognostic impact in our adult cohort ( $p=0.877$ ). Most frequently mutated genes were TERT (including promoter mutations, mutated in $36 \%$ cases), chromatin modifiers KMT2D (31\%) and KMT2C (30\%), TCF4 (31\%), PTCH1 (27\%) and DDX3X (24\%). Adult WNT patients showed enrichment of TP53 mutations (6/15 WNT cases), and 3/6 TP53-mutant WNT tumours were of large cell/ anaplastic histology.Adult SHH medulloblastomas had frequent upstream pathway alterations (PTCH1 and SMO mutations) and few downstream alterations (SUFU mutations, MYCN amplifications). TERT promoter mutations were found in $72 \%$ of adult SHH patients, and were restricted to this group. Adult Group 3 tumours lacked hallmark MYC amplifications, but had recurrent mutations in KBTBD4 and NOTCH1. Adult Group 4 tumours harboured recurrent mutations in TCF4 and chromatin modifier genes. Overall, amplifications of MYC and MYCN were rare (3\%). Since molecular groups were not prognostic, alternative prognostic markers are needed for adult medulloblastoma. KMT2C mutations were frequently found across molecular groups and were associated with poor survival $(p=0.002)$. Multivariate analysis identified histological type $(p=0.026)$, metastasis $(p=0.031)$ and KMT2C mutational status $(p=0.046)$ as independent prognosticators in our cohort. In summary, we identified distinct clinical and mutational characteristics of adult medulloblastomas that will inform their risk stratification and treatment.
\end{abstract}

Keywords: Adult medulloblastoma, Molecular group, Targeted sequencing, TP53, MYC, KMT2C

*Correspondence: gabrielchunhei@gmail.com; yingmao168@hotmail.com neurozzy@foxmail.com; shizhifeng@fudan.edu.cn

${ }^{\dagger}$ Gabriel Chun-Hei Wong, Kay Ka-Wai Li and Wei-Wei Wang have contributed equally

${ }^{1}$ Department of Anatomical and Cellular Pathology, The Chinese University of Hong Kong, Shatin, Hong Kong

${ }^{6}$ Department of Neurosurgery, The First Affiliated Hospital of Zhengzhou University, Zhengzhou, China

${ }^{7}$ Department of Neurosurgery, Huashan Hospital, Fudan University, Shanghai, China

Full list of author information is available at the end of the article

\section{Introduction}

Medulloblastoma is one of the most common malignant brain tumours in children [52]. Medulloblastomas are now classified into four major molecular groups (WNTactivated, SHH-activated, Group 3, and Group 4) with distinct clinical, genetic and transcriptomic profiles [23, 32, 39, 67]. WNT medulloblastoma patients have the best 5 -year overall survival rate of over $90 \%$, while Group 3 patients have the worst 5-year overall survival rate of merely $50 \%$ [30]. Molecular groups have been incorporated into risk stratification and treatment algorithms 
of medulloblastoma [22, 48]. For instance, clinical trials are investigating the reduction of irradiation dose to low-risk WNT patients (NCT01878617, NCT02724579, NCT02066220).

In adults, medulloblastomas account for less than $1 \%$ of central nervous system (CNS) tumours [52]. Due to their rarity, prospective trials on adult medulloblastomas are limited [40]. The management of adult medulloblastomas is adapted from paediatric protocols, often resulting in dose-limiting toxicities [12].

There is evidence of clinical and genetic differences between adult and paediatric medulloblastomas, suggesting that adult medulloblastomas should be treated and stratified for risk differently [4, 34]. Clinically, adult medulloblastomas more commonly occur in the cerebellar hemispheres [5], are infrequently metastatic at diagnosis [30], and characteristically present with late relapses [3, 10, 52]. Histologically, large cell/anaplastic (LCA) features are less frequently found in adult than in paediatric medulloblastomas [30]. Molecularly, $\mathrm{SHH}$ is the predominant group in adult medulloblastomas, while Group 3 is rare [2, 30, 58, 74]. The survival outcomes of molecular groups in adult medulloblastoma have been inconsistent in the literature [30,58,74], although some studies suggest that adult WNT patients do not share the excellent survival of paediatric WNT patients [21, $58,65]$, and adult $\mathrm{SHH}$ patients have relatively favourable survival compared to paediatric SHH patients [6, 65]. Adult medulloblastomas also have distinct cytogenetic profiles from paediatric patients, with chromosome $10 \mathrm{q}$ loss and $17 \mathrm{q}$ gain proposed as prognostic markers in adults $[31,46]$.

Despite these initial findings, genome sequencing studies on adult medulloblastomas are still lacking. Knowledge on genetic aberrations in adult medulloblastomas is mostly limited to the SHH group [29, 46]. Comprehensive evaluation of adult medulloblastoma is needed to inform its risk stratification and treatment.

In this study, we report the clinical and mutational profiles of 99 adult medulloblastomas, investigated for molecular group, coding mutations, TERT promoter mutations, MYC and MYCN amplifications, and survival outcome.

\section{Materials and methods}

\section{Tumour material and patient characteristics}

Tumour samples and clinicopathological information were collected from 99 adult medulloblastoma patients between years 2005 and 2018, from the Prince of Wales Hospital (Hong Kong), Huashan Hospital (Shanghai) and the First Affiliated Hospital of Zhengzhou University (Zhengzhou). Local ethics approvals were obtained from The Joint Chinese University of Hong Kong-New
Territories East Cluster Clinical Research Ethics Committee, and the Ethics Committees of Huashan Hospital, Shanghai and The First Affiliated Hospital of Zhengzhou University, Zhengzhou. Clinical information was retrieved from institutional paper and electronic records. Survival data was obtained from follow-up clinic visits and direct contact with patients or close relatives via phone.

Haematoxylin and eosin-stained (H\&E) slides of all cases were centrally reviewed (H.K.N., A.K.C.) for confirmation of diagnosis and assignment of histological type. All patients were aged $>18$ years at the time of diagnosis.

\section{Molecular group affiliation}

The medulloblastomas were assigned to molecular groups by NanoString assay as described by Northcott et al. [50], a transcription-based classification method that is suitable for formalin-fixed paraffin embedded (FFPE) tissues [13, 51]. In brief, RNA was extracted from FFPE tissues using RNeasy FFPE Kit (Qiagen), then quantified by NanoDrop 2000 spectrophotometer (Thermo Scientific). 100 ng RNA per sample was then hybridised to the NanoString nCounter CodeSet at $67^{\circ} \mathrm{C}$ for $20 \mathrm{~h}$. The custom CodeSet contained gene-specific probes that assayed the abundance of 22 medulloblastoma group-specific genes and 3 housekeeping genes [50]. Hybridisation complexes were purified with magnetic beads and immobilised on a streptavidin-coated cartridge using the nCounter Prep Station (NanoString Technologies) according to the manufacturer's protocol. Signals of fluorescent barcodes representing individual target RNA molecules were then counted and recorded by the nCounter Digital Analyzer (NanoString Technologies). Using an R script kindly provided to us by Prof. Michael Taylor, raw data was normalised with $\mathrm{R}$ package 'NanoStringNorm', and group predictions were made with package 'pamr' [50]. NanoString raw counts, expression heatmap and group prediction results can be found in supplementary data (Additional file 1: Figure S1, Additional file 2: Table S2).

\section{Targeted DNA sequencing, variant and copy number calling}

DNA was extracted from FFPE tissues using GeneRead DNA FFPE Kit (Qiagen), then qualified and quantified with QIAseq DNA QuantiMIZE Assay Kit. Targeted next-generation sequencing (NGS) libraries were prepared with a custom QIAseq Targeted DNA Panel, covering the coding exons of 69 genes altered in medulloblastoma and other CNS tumours (Additional file 2: Table S3). The 260-kilobase target region was sequenced with MiSeq v3 (Illumina) to $369.45 \times$ mean coverage per sample (range 99.76-1457.32). 
Paired-end reads were aligned to the hg19 (GRCh37) build of the human reference genome with BWA-MEM on GeneGlobe platform (Qiagen). Variants were called using smCounter2 [69] and annotated using wANNOVAR [70]. We excluded variants that did not pass quality filters [69], had variant allele fractions of $<5 \%$ or variant allele counts of $<5$, or had minor allele frequencies of $>1 \%$ in East Asians or the overall human population (as documented in 1000 Genomes, ExAc, gnomAD exome and genome databases). Non-synonymous single nucleotide variants (SNVs) and insertions/deletions (indels) in exonic regions were visualised using Oncoprinter and MutationMapper on cBioPortal [7, 19].

Focal gene-level copy numbers for MYC and MYCN were called using the quandico algorithm [57], with 8 non-tumour brain samples as controls. Amplification was defined as copy number $>10$.

\section{Sanger sequencing for TERT promoter hotspot mutations}

A previous whole genome sequencing study identified the TERT promoter as the only non-coding region that is recurrently mutated in medulloblastoma [45]. Accordingly, we performed Sanger sequencing to evaluate the mutational hotspots of TERT promoter, C228T and C250T (124 and 146 bp upstream of the ATG start site respectively), as previously described $[1,8,9,37,64,71$, 72].

Tumour tissues were scraped off FFPE sections, placed in $10 \mathrm{mM}$ Tris- $\mathrm{HCl}$ buffer ( $\mathrm{pH} \mathrm{8.5)}$ with proteinase $\mathrm{K}$, and incubated at $56{ }^{\circ} \mathrm{C}$ overnight followed by $98{ }^{\circ} \mathrm{C}$ for $10 \mathrm{~min}$. The lysate was then spin down at full speed and the supernatant was collected for subsequent PCR reaction. The $20 \mu \mathrm{l}$ amplification reaction contained $0.5 \mu \mathrm{l}$ cell lysate, $0.3 \mu \mathrm{M}$ forward (5'-GTCCTGCCCCTTCAC CTT- $3^{\prime}$ ) and reverse (5'-CAGCGCTGCCTGAAACTC $\left.-3^{\prime}\right)$ primers, and $10 \mu \mathrm{l}$ KAPA HiFi HotStart ReadyMix (Sigma). PCR conditions consisted of $95{ }^{\circ} \mathrm{C}$ for $5 \mathrm{~min}$; followed by 45 cycles of $98{ }^{\circ} \mathrm{C}$ for $20 \mathrm{~s}, 68{ }^{\circ} \mathrm{C}$ for $15 \mathrm{~s}$, and $72{ }^{\circ} \mathrm{C}$ for $30 \mathrm{~s}$; and finally, $72{ }^{\circ} \mathrm{C}$ for $1 \mathrm{~min}$, on Veriti 96-Well Thermal Cycler (Applied Biosystems). PCR products were cleaned with spin column-based nucleic acid purification kit (iNtRON Biotechnology) and sequenced with BigDye Terminator Cycle Sequencing kit v1.1 (Life Technologies). The products were resolved in 3130xl Genetic Analyzer (Applied Biosystems). All mutations were confirmed by sequencing of a newly amplified fragment.

\section{Statistical analysis}

Statistical analyses were performed using IBM SPSS Statistics Version 22.

Overall survival (OS) was defined as the time from tumour diagnosis to death or last follow-up.
Progression-free survival (PFS) was defined as the time from diagnosis to recurrence or progression as evidenced by radiological imaging, or last follow-up. Univariate analysis was performed on OS using the Kaplan-Meier method and log-rank test. For multivariate analysis, Cox proportional hazards model was applied with OS as the outcome variable. Significance level of $\alpha=0.05$ (twotailed) was used. For multiple comparisons of molecular markers, the Benjamini-Hochberg procedure was employed to control the false discovery rate at $\mathrm{Q}=0.05$.

\section{Results}

\section{Clinical characteristics of adult medulloblastomas}

Our cohort consisted of 99 adult medulloblastomas aged above 18 at diagnosis. The median age at diagnosis was 27 (range 19-63). There was a trend of decreasing incidence with age in this cohort, with nearly 60\% (58/99) of patients between 19 and 29 years (Table 1). Male-tofemale ratio was 1.8:1. The tumours were more frequently located in the cerebellar hemispheres than in the vermis (Table 1$)$. Less than $10 \%(8 / 82)$ were metastatic at diagnosis (Fig. 1b). 62\% (61/99) of the tumours exhibited classic histology, whereas desmoplastic/nodular and LCA accounted for 29\% (29/99) and 9\% (9/99) respectively. In terms of treatment, $85 \%(62 / 73)$ of patients achieved gross total resection. 53\% (39/73) received both adjuvant chemotherapy and radiotherapy, 30\% (22/73) received radiotherapy only, $4 \%(3 / 73)$ received chemotherapy only, and $12 \%(9 / 73)$ received no adjuvant therapy.

We were able to study the survival of 78 patients. The mean and median follow-up were 60.2 and 52.0 months respectively. Median OS and PFS were 102 and 99 months respectively. Among histological types, desmoplastic/nodular tumours had the best outcome whereas LCA had the worst $(p=0.027$, desmoplastic/ nodular vs LCA). The clinical factors with the strongest prognostic impact were metastasis $(p=0.005)$ and adjuvant therapy $(p<0.001)$ (Additional file 1: Figure S2).

\section{Molecular groups of adult medulloblastomas}

As expected, the $\mathrm{SHH}$ group comprised half (49/99) of the adult medulloblastomas in our cohort (Fig. 1a). $\mathrm{SHH}$ was further enriched in older adults, making up $68 \%(28 / 41)$ of those aged 30 or above. Notably, Group 3 formed 13\% (13/99) of our adult cohort (Additional file 1: Figure S3). WNT accounted for 19\% (19/99) of cases, and Group 4 accounted for $18 \%$ (18/99).

The four molecular groups varied in sex ratio, metastatic rate, and histological distribution (Fig. 1b). WNT was the only group which showed female preponderance, while Group 4 showed the highest male-to-female ratio of 5:1. Group 4 also had the highest metastatic rate among the four groups. Histological type was 
Table 1 Summary of clinical characteristics of adult medulloblastoma patients

\begin{tabular}{|c|c|c|}
\hline & $\mathrm{N}$ & $\%$ \\
\hline \multicolumn{3}{|l|}{ Age } \\
\hline $18-23$ & 29 & 29.3 \\
\hline $24-29$ & 29 & 29.3 \\
\hline $30-35$ & 15 & 15.2 \\
\hline $36-41$ & 13 & 13.1 \\
\hline $42-47$ & 7 & 7.1 \\
\hline $48-53$ & 4 & 4.0 \\
\hline$>53$ & 2 & 2.0 \\
\hline \multicolumn{3}{|l|}{ Sex } \\
\hline M & 64 & 64.6 \\
\hline $\mathrm{F}$ & 35 & 35.4 \\
\hline \multicolumn{3}{|l|}{ Location } \\
\hline Cerebellar hemisphere & 34 & 34.7 \\
\hline Cerebellar vermis & 21 & 21.4 \\
\hline Cerebellum, NOS & 11 & 11.2 \\
\hline Fourth ventricle & 21 & 21.4 \\
\hline Others & 11 & 11.2 \\
\hline Unknown & 1 & - \\
\hline \multicolumn{3}{|l|}{ Metastasis } \\
\hline $\mathrm{M}+$ & 8 & 9.8 \\
\hline$M-$ & 74 & 90.2 \\
\hline Unknown & 17 & - \\
\hline \multicolumn{3}{|l|}{ Histological type } \\
\hline Classic & 61 & 61.6 \\
\hline Desmoplastic/nodular & 29 & 29.3 \\
\hline Large cell/anaplastic & 9 & 9.1 \\
\hline \multicolumn{3}{|l|}{ Resection extent } \\
\hline Gross total resection & 62 & 84.9 \\
\hline Subtotal resection & 11 & 15.1 \\
\hline Unknown & 26 & - \\
\hline \multicolumn{3}{|l|}{ Adjuvant therapy } \\
\hline Chemotherapy and radiotherapy & 39 & 53.4 \\
\hline Radiotherapy only & 22 & 30.1 \\
\hline Chemotherapy only & 3 & 4.1 \\
\hline No adjuvant therapy & 9 & 12.3 \\
\hline Unknown & 26 & - \\
\hline
\end{tabular}

NOS not otherwise specified

significantly associated with molecular group $(p<0.001$, Chi squared test), with $90 \%(26 / 29)$ of desmoplastic/ nodular tumours belonging to the $\mathrm{SHH}$ group.

Unlike paediatric medulloblastomas, molecular groups had no impact on overall survival in our adult medulloblastoma cohort $(p=0.877)$ (Fig. 1c). The 5 -year OS rate of WNT tumours in our cohort was $45 \%$, in contrast to the over $90 \% 5$-year OS rate characteristically attributed to paediatric WNT [30].
Mutational profiles of adult medulloblastomas

We performed targeted sequencing on 70 cases with sufficient tissues, including 15 WNT, $33 \mathrm{SHH}, 10$ Group 3, and 12 Group 4 tumours. The mutational load differed significantly between groups $(p<0.001$, Kruskal-Wallis test): WNT, SHH, Group 3 and Group 4 each recorded a median of 7, 6, 3 and 2.5 mutations per case respectively.

The most frequently mutated genes were TERT (including promoter mutations, mutated in $36 \%$ of cases which underwent NGS), KMT2D (31\%), TCF4 (31\%), KMT2C (30\%), PTCH1 (27\%) and DDX3X (24\%) (Fig. 2). Among these, TERT promoter mutations were restricted to the SHH group, while PTCH1 and DDX3X mutations were mostly found in WNT and SHH. KMT2C, KMT2D and TCF4 mutations were seen across all four groups.

Amplification of MYC was not found throughout the adult cohort, while two $\mathrm{SHH}$ cases showed highlevel MYCN amplifications (Fig. 2, Additional file 2: Table S6).

\section{WNT group}

$14 / 15$ of the sequenced WNT cases carried hotspot mutations in CTNNB1, all concentrated in amino acid positions D32-S37 (particularly S33) (Additional file 1: Figure S4a). 2 cases were mutated in APC. Interestingly, canonical $\mathrm{SHH}$ pathway genes were also altered in the WNT group: 5 WNT cases harboured PTCH1 truncating mutations that co-occurred with CTNNB1 mutations, and another case showed mutations in both APC and SMO (Additional file 1: Figure S5).

Mutations in TP53 were found in 40\% (6/15) of our adult WNT cases (Fig. 3a), a much higher proportion than the $13-16 \%$ reported in WNT tumours within paediatric-predominant cohorts [45, 47, 75]. All TP53 mutations in WNT occurred within the p53 DNA binding domain (Fig. 3b). Half (3/6) of the TP53-mutant WNT tumours showed LCA histology (Fig. 3c), while all of the TP53-wildtype WNT tumours displayed classic histology.

Other frequently mutated genes in WNT included DDX3X (47\%) and FBXW7 (27\%). Mutations in DDX3X concentrated in its two helicase domains (Additional file 1: Figure S4d), whereas an $\mathrm{R} 385 \mathrm{C} / \mathrm{H}$ hotspot was identified in FBXW7 (Additional file 1: Figure S4e).

\section{SHH group}

Among the SHH pathway genes, PTCH1 was mutated in $36 \%(12 / 33)$ of adult $\mathrm{SHH}$ medulloblastomas, and SMO was mutated in 27\% (9/33) (Fig. 2). Most (11/12) PTCH1 mutations were truncating (Additional file 1: 
a

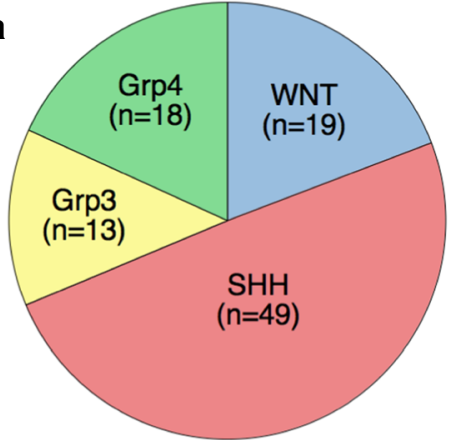

Full Cohort $(n=99)$

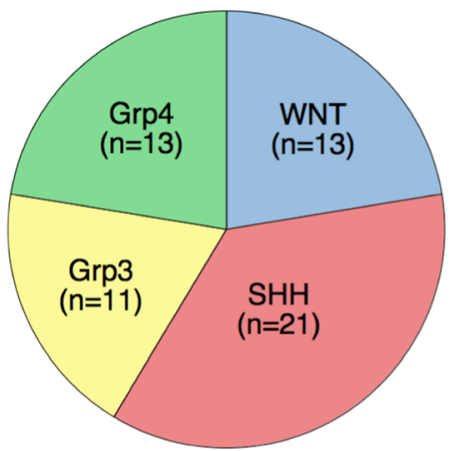

Age 18-29 $(n=58)$

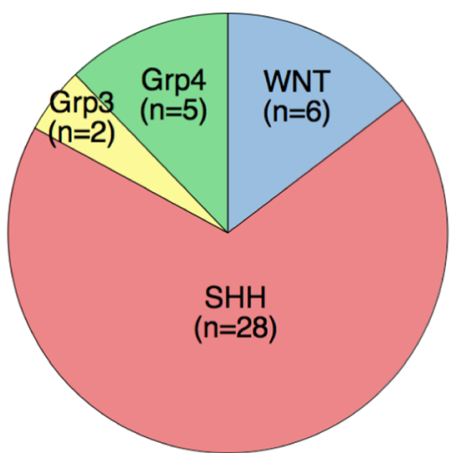

Age $\geq 30(n=41)$

b

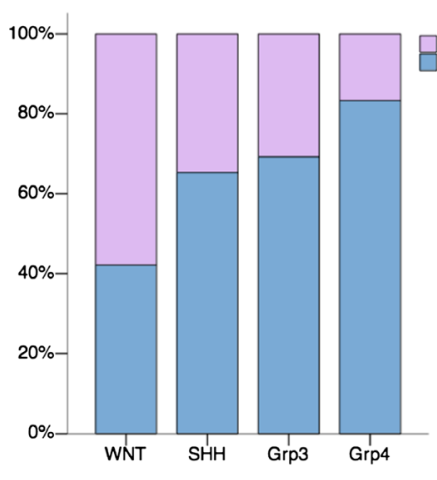

Sex Ratio
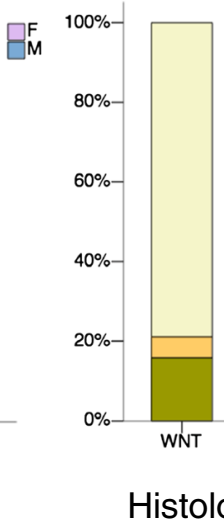
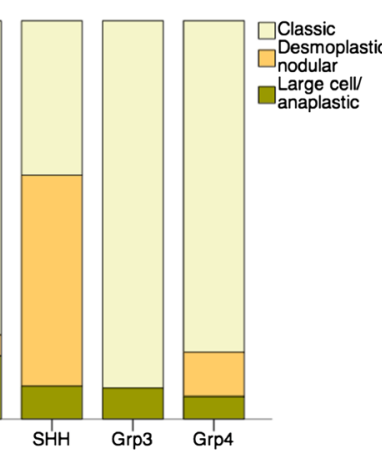

Histological Distribution

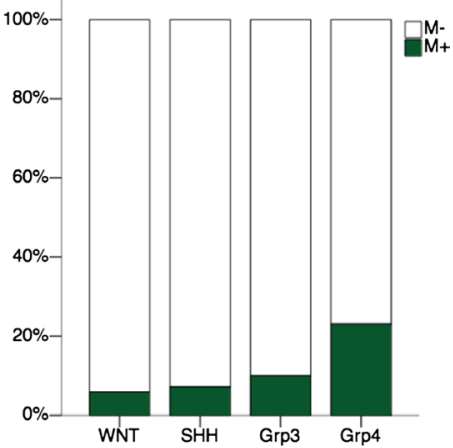

Metastatic Rate

C

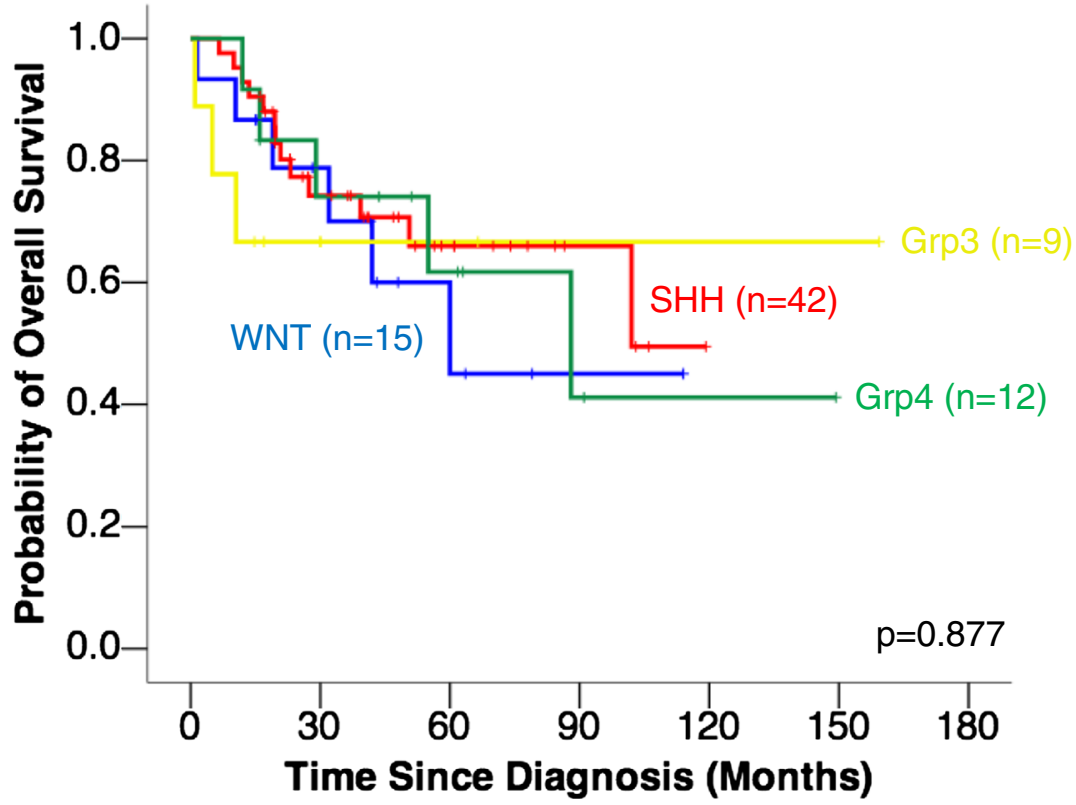

Fig. 1 Molecular groups of adult medulloblastomas. a The SHH group made up half (49/99) of the cohort. In older adults (age $\geq 30$ ), SHH accounted for $68 \%$ (28/41) of cases. Group 3 formed $13 \%$ of our adult cohort. $\mathbf{b}$ The four groups showed differences in sex ratios, histological distributions and metastatic rates. c Molecular groups had no prognostic impact $(p=0.877)$ in adult medulloblastomas 


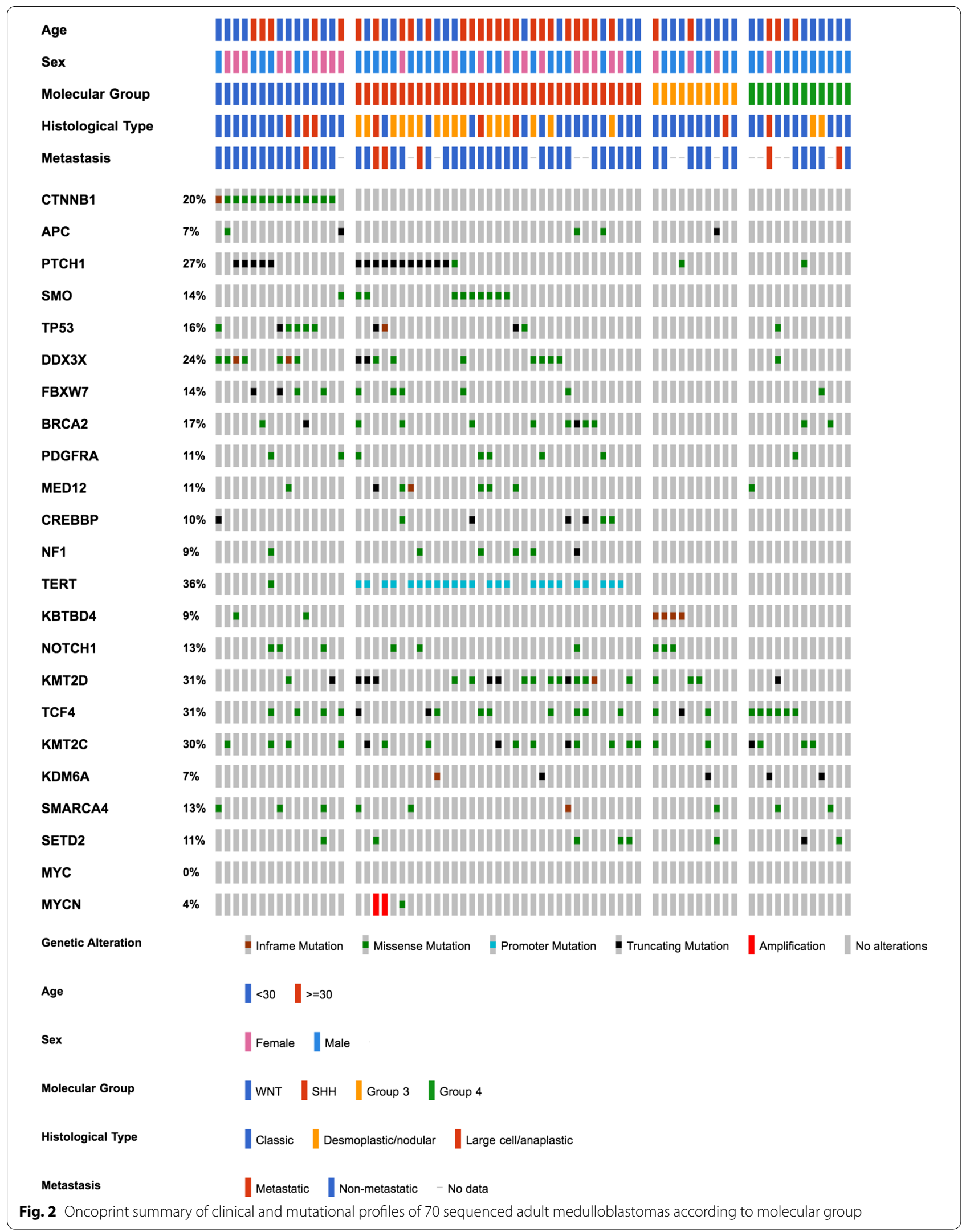




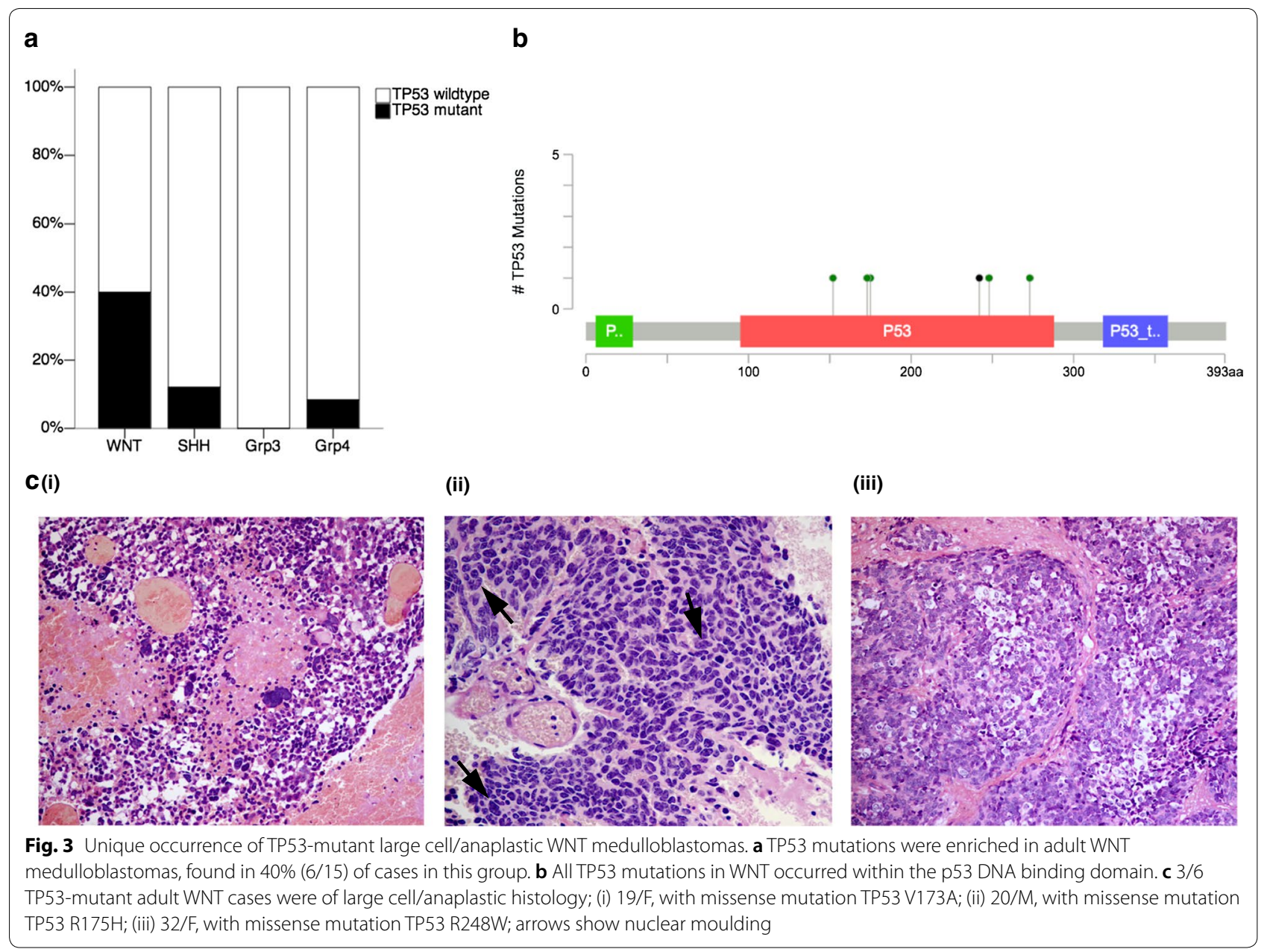

Figure S4f), whereas SMO mutations mainly (8/9) consisted of a hotspot substitution L412F (Additional file 1: Figure S4g). No SUFU mutation was found in adult SHH, consistent with previous studies [29, 45].

TERT promoter mutations were limited to the $\mathrm{SHH}$ group, detected in $72 \%(34 / 47)$ of adult SHH cases. C228T was found in 28 cases, whereas C250T was found in 4; one case showed C228A and another showed C250G (Additional file 1: Figure S6, Additional file 2: Table S5).

Other prevalently seen mutations in adult $\mathrm{SHH}$ included those of DDX3X (27\%), BRCA2 (24\%), MED12 (18\%), CREBBP (18\%), FBXW7 (15\%), PDGFRA (15\%) and NF1 (15\%). DDX3X, CREBBP and FBXW7 mutations were reported to be very rare in paediatric $\mathrm{SHH}$ [29, 45]. TP53 mutations were rarer than in WNT, present in $12 \%(4 / 33)$ of SHH cases.

MYCN amplification was found in $2 \mathrm{SHH}$ cases. The 2 cases exhibited high-level amplifications, with 123 and 78 copies respectively (Additional file 2: Table S6). Both of these cases had concomitant TP53 mutation and were metastatic (Fig. 2).

\section{Group 3}

Hotspot in-frame insertions of KBTBD4 were found in $40 \%(4 / 10)$ of Group 3 cases (Additional file 1: Figure S4h). NOTCH1, KMT2D and TCF4 were each mutated in 3 cases. Of these, all NOTCH1 mutations co-occurred with KBTBD4 insertions.

MYC amplification, a hallmark high-risk feature almost exclusive to Group 3 [45, 47, 49], was absent in our adult cohort, including in Group 3 tumours (Fig. 2).

\section{Group 4}

TCF4 mutations were found in half (6/12) of the Group 4 cases. All 6 mutations consisted of a missense substitution Q95R, a hotspot that was identified across groups (Additional file 1: Figure S4j). Other recurrently mutated genes in Group 4 included chromatin modifiers KMT2C (4/12), KDM6A (2/12), SETD2 (2/12) and SMARCA4 (2/12).

No Group 4 cases harboured MYCN amplification (Fig. 2). 


\section{Chromatin modification genes}

Overall, mutations in genes related to chromatin modification were found in $81 \%(57 / 70)$ of samples, distributed across all four groups (Additional file 1: Figure S7). These genes included histone modifiers and their interacting proteins (KMT2D, KMT2C, KDM6A, SETD2, CREBBP, BCOR, GSE1, ZMYM3), SWI/SNF-nucleosome remodelling complex subunits (SMARCA4, SMARCB1, ARID1A, ARID2), as well as histones (H3F3A) and their chaperones (ATRX).

\section{Prognostication of adult medulloblastomas}

Since molecular groups had no impact on the overall survival of adult medulloblastoma patients (Fig. 1c), we assessed the prognostic significance of frequently mutated genes in our cohort. Presence of KMT2C mutation was associated with poor outcome $(p=0.002$, $q=0.034$ ) (Table 2, Fig. 4a). KMT2C mutations were present in $30 \%$ of adult medulloblastoma cases, distributed across all four molecular groups (Fig. 4b). At the gene level, mutations were scattered across the coding region of KMT2C (Fig. 4c).

Upon multivariate analysis, KMT2C mutation remained as an independent poor prognosticator (hazard ratio $(\mathrm{HR})=6.468, p=0.046$ ) after adjusting for age, sex, molecular group, histological type, metastasis and

\begin{tabular}{|c|c|c|c|}
\hline Gene & $\begin{array}{l}\text { Mutational } \\
\text { frequency (\%) }\end{array}$ & $\begin{array}{l}\text { OS log-rank } \\
p \text { value }\end{array}$ & $\begin{array}{l}\text { Benjamini- } \\
\text { Hochberg } 9 \\
\text { value }\end{array}$ \\
\hline TERT promoter & $39^{\mathrm{a}}$ & 0.294 & 0.460 \\
\hline KMT2D & 31 & 0.056 & 0.334 \\
\hline TCF4 & 31 & 0.282 & 0.460 \\
\hline KMT2C & 30 & 0.002 & 0.034 \\
\hline PTCH1 & 27 & 0.356 & 0.460 \\
\hline DDX3X & 24 & 0.969 & 0.969 \\
\hline CTNNB1 & 20 & 0.565 & 0.640 \\
\hline BRCA2 & 17 & 0.337 & 0.460 \\
\hline TP53 & 16 & 0.062 & 0.334 \\
\hline FBXW7 & 14 & 0.118 & 0.334 \\
\hline SMO & 14 & 0.101 & 0.334 \\
\hline $\mathrm{NOTCH1}$ & 13 & 0.379 & 0.460 \\
\hline SMARCA4 & 13 & 0.172 & 0.418 \\
\hline PDGFRA & 11 & 0.873 & 0.928 \\
\hline MED12 & 11 & 0.102 & 0.334 \\
\hline SETD2 & 11 & 0.257 & 0.460 \\
\hline CREBBP & 10 & 0.314 & 0.460 \\
\hline
\end{tabular}

Bold values are $p<0.05$ and $q<0.05$

a $34 / 88$ cases by Sanger sequencing adjuvant therapy (Table 3). Other independent prognosticators included histological type $(p=0.026)$ and metastasis $(p=0.031)$. Molecular groups continued to show no prognostic impact in the multivariate model $(p=0.407)$.

\section{Discussion}

In this study, we showed that molecular groups have no prognostic significance in adult medulloblastomas. This is in contrast to paediatric medulloblastomas where molecular groups have been integrated into risk stratification schemes $[55,56]$. In particular, WNT status was not associated with favourable survival in our adult cohort, in agreement with a previous study by Korshunov et al. [31]. With the increased interest in the feasibility of reducing irradiation dose to WNT patients [44], caution should be taken in applying such treatment de-escalation approaches to adult WNT patients.

When examining the mutational profiles of adult WNT medulloblastomas, we discovered a high frequency of TP53 mutations, compared to paediatric WNT. TP53 mutations have been reported in $13-16 \%$ of WNT medulloblastomas [45, 47, 75], whereas in our adult cohort, TP53 mutations were detected in $40 \%$ of WNT cases. Re-analysis of data from Northcott et al. gave a similar result, where $2 / 4$ adult WNT tumours harboured TP53 mutations, compared to only $3 / 29$ paediatric WNT tumours in their cohort [45]. TP53 has been shown to play a role in WNT pathophysiology: excess $\beta$-catenin promotes accumulation of transcriptionally active p53 [14], and activated p53 in turn downregulates $\beta$-catenin $[35,62]$, indicating that p53 mediates an important tumour suppressive mechanism against WNT pathway activation. Gibson et al. showed that concomitant TP53 deletion was required to induce medulloblastoma formation in CTNNB1-mutant mice [20]. The abundance of TP53 mutations in adult WNT may partly account for the biological and clinical differences observed between adult and paediatric WNT tumours.

Apart from the significant enrichment of TP53 mutations in adult WNT, we also observed that a high proportion of TP53-mutant adult WNT tumours shared the high-risk feature of LCA histology. This is in contrast to the mostly paediatric cohort in Zhukova et al., where none of the TP53-mutant WNT tumours showed anaplastic features [75]. The unique occurrence of TP53mutant LCA WNT tumours, and the heterogeneous treatments received [44], may be reasons for the lack of favourable survival for WNT patients in our adult cohort.

Another striking feature of adult WNT medulloblastomas is the concurrent mutations of WNT and $\mathrm{SHH}$ pathway genes. This coincides with the recent observations by Iorgulescu et al., who found $\mathrm{SHH}$ pathway mutations at subclonal allele frequencies in $3 / 7$ of their 


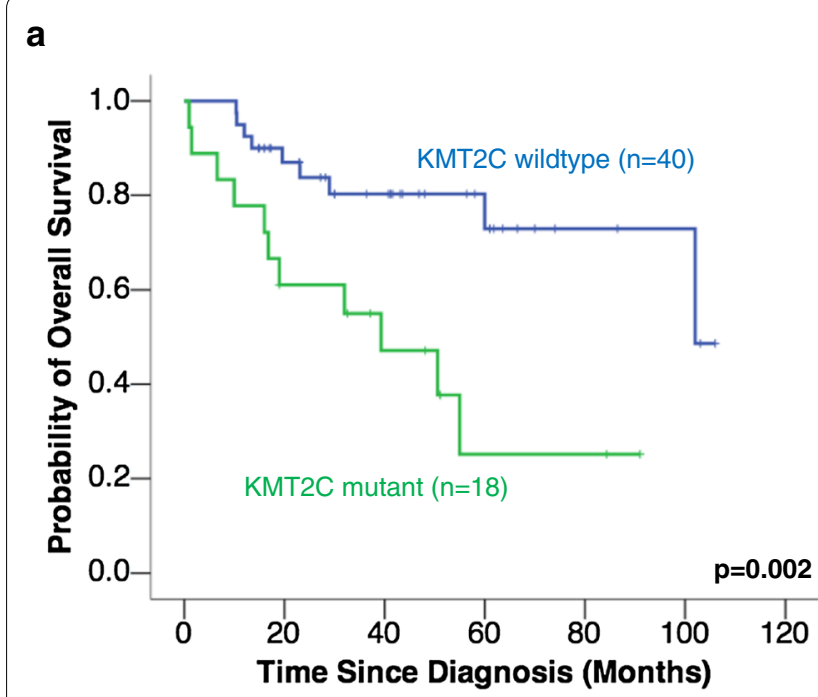

b

C
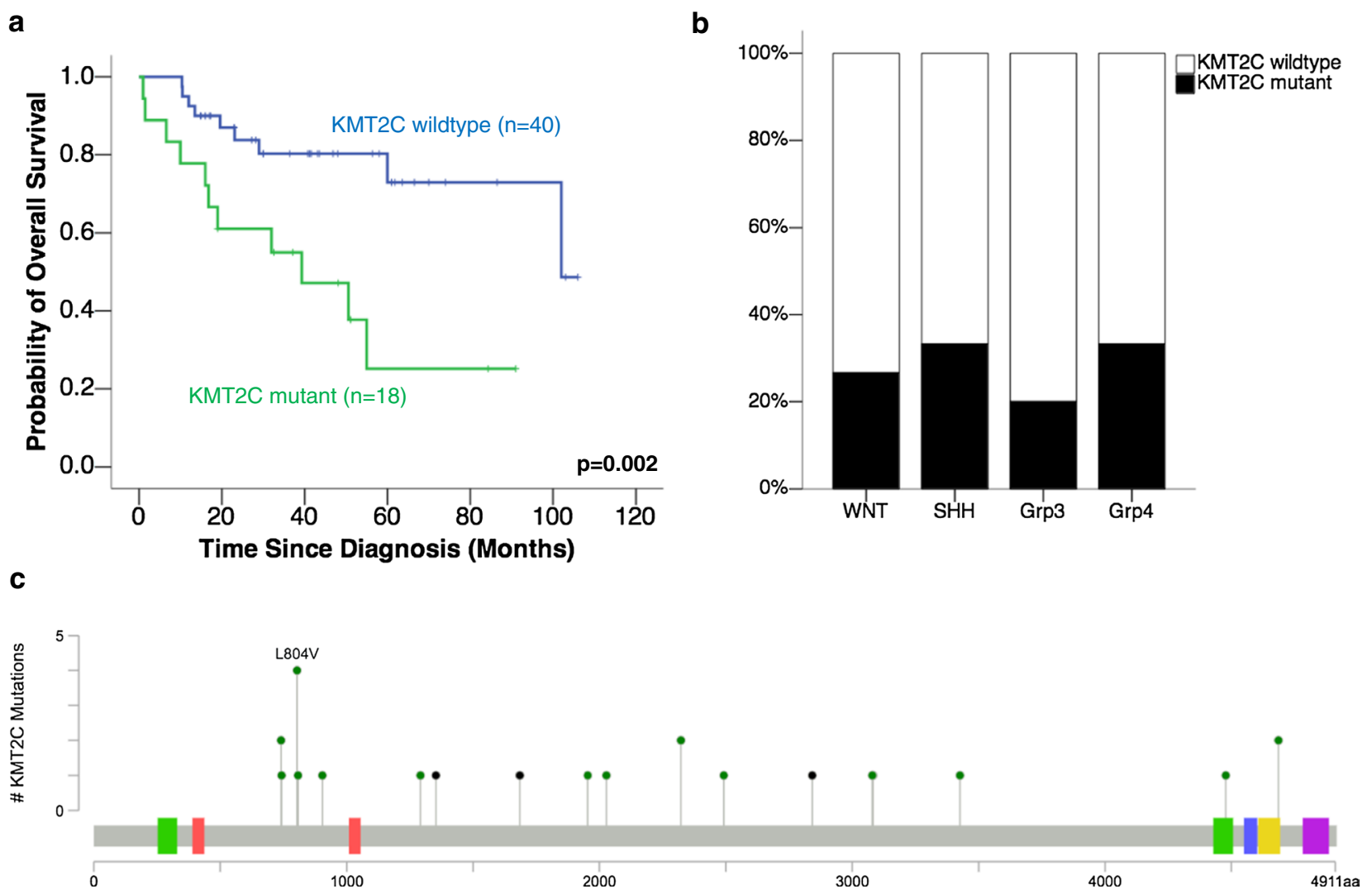

Fig. $4 \mathrm{KMT2C}$ mutations as a poor prognostic marker in adult medulloblastomas. a KMT2C mutation was associated with poor overall survival $(p=0.002)$. b KMT2C mutations were found in 30\% of adult medulloblastomas across molecular groups. c KMT2C mutations were scattered across the coding region of the gene

Table 3 Multivariate analysis of clinical and molecular prognosticators in adult medulloblastomas

\begin{tabular}{lcl}
\hline & HR (95\% Cl) & $\boldsymbol{p}$ value \\
\hline Age & $0.869(0.755-1.002)$ & 0.053 \\
Sex (male versus female) & $27.878(0.382-2035.342)$ & 0.128 \\
Molecular group & & 0.407 \\
SHH versus WNT & $0.894(0.022-36.018)$ & 0.953 \\
Group 3 versus WNT & $5.903(0.225-155.063)$ & 0.287 \\
Group 4 versus WNT & $0.306(0.006-14.994)$ & 0.551 \\
Histological type & & $\mathbf{0 . 0 2 6}$ \\
Desmoplastic/nodular versus & $0.467(0.046-4.746)$ & 0.520 \\
$\quad$ classic & & \\
LCA versus classic & $129.534(2.871-5844.831)$ & $\mathbf{0 . 0 1 2}$ \\
Metastasis & $7.78(1.207-50.147)$ & $\mathbf{0 . 0 3 1}$ \\
Adjuvant therapy & $0.283(0.007-11.612)$ & 0.506 \\
KMT2C mutation & $6.468(1.035-40.404)$ & $\mathbf{0 . 0 4 6}$ \\
\hline
\end{tabular}

Bold values are $p<0.05$ and $q<0.05$

CTNNB1-mutant medulloblastomas [25]. They subsequently performed immunohistochemistry for GAB1, which yielded a focal staining pattern that confirmed secondary $\mathrm{SHH}$ pathway activation, reflecting intratumoural heterogeneity within these WNT medulloblastomas. Medulloblastomas have been shown to exhibit substantial spatial heterogeneity in genetic alterations, which points toward the need for multi-regional biopsies and combination targeted therapies [43].

$\mathrm{SHH}$ is the predominant group in adult medulloblastomas, and adult $\mathrm{SHH}$ tumours are characterised by upstream pathway mutations in PTCH1 and SMO, whereas downstream pathway alterations such as SUFU mutations and MYCN amplifications are rare in this age group. Our findings are similar to those of Kool et al., who also found that a large proportion of adult $\mathrm{SHH}$ tumours are targetable by the SMO inhibitor LDE-225 (sonidegib), due to the rarity of $\mathrm{SHH}$ pathway alterations downstream to SMO which confer therapeutic resistance [29]. A phase II trial showed clinical efficacy of the SMO inhibitor vismodegib in adult recurrent $\mathrm{SHH}$ medulloblastoma [60].

The strong enrichment of TERT promoter mutations in adult $\mathrm{SHH}$ medulloblastomas has been reported by 
multiple studies $[28,29,38,59]$. In addition to the TERT promoter, our study confirmed that gene mutations in DDX3X, CREBBP and FBXW7, which are rare in paediatric $\mathrm{SHH}[29,45]$, occur frequently in adult $\mathrm{SHH}$; on the other hand, TP53 mutations which are abundant in paediatric SHH are rarely seen in adults. In 2017, Cavalli et al. further classified $\mathrm{SHH}$ medulloblastomas into four age-associated subtypes based on integrated methylation and expression profiling data [6]. Most adult $\mathrm{SHH}$ cases belonged to the $\mathrm{SHH}-\delta$ subtype which was highly enriched for TERT promoter mutations and had relatively favourable survival, further substantiating the hypothesis that adult $\mathrm{SHH}$ tumours represent a biologically disparate entity from paediatric and infant $\mathrm{SHH}$ tumours.

While previous studies found that Group 3 is extremely rare or absent in adult medulloblastomas [30, 58, 74], our cohort showed that Group 3 could make up a significant proportion of adult medulloblastomas, and that adult Group 3 patients did not have worse outcome than the other groups. We also showed that MYC amplification, the hallmark driver event detected in 12-17\% of Group 3 medulloblastomas [45, 47, 49], was absent in adult Group 3 tumours. MYC amplification is a well-established poor prognosticator in various risk stratification models [15, $16,55,61,65]$, thus the lack of this group-specific marker in adult medulloblastoma might explain why Group 3 patients did not exhibit worse survival than the other groups in our adult cohort.

We also identified other genetic events in adult Group 3, such as KBTBD4 hotspot insertions described earlier by Northcott et al. [45], as well as NOTCH1 mutations which are rare in paediatric Group 3. Kahn et al. recently reported that $\mathrm{NOTCH} 1$ signaling regulates the initiation of metastasis and self-renewal of Group 3 medulloblastoma, and intrathecal treatment with a NOTCH1 blocking antibody reduced spinal metastasis and improved survival in vivo [27]. These findings propose NOTCH1 signaling as a potential driver and therapeutic target in Group 3, alongside MYC activation and KBTBD4 insertions [42].

TCF4 mutations were a frequent event in our adult Group 4 medulloblastomas. TCF4 was also one of the most frequently mutated genes in our whole cohort. TCF4 is a transcription factor involved in neurological development and is mutated in $2 \%$ of medulloblastomas [45]. Re-analysis of sequencing data from Northcott et al. revealed that TCF4 mutations were enriched in adults, present in $17 \%(10 / 58)$ of adult cases. Whether TCF4 mutations play any functional role in medulloblastoma remains a topic for further investigation.
Lastly, the lack of prognostic impact of molecular groups warrants the discovery of alternative prognostic markers in adult medulloblastoma. In addition to histological type and metastasis, we identified KMT2C mutational status as an independent prognosticator in our cohort. KMT2C, also known as MLL3, is a histone lysine methyltransferase that catalyses the monomethylation of histone $\mathrm{H} 3$ lysine 4 (H3K4me) at gene enhancers [24]. KMT2C has a tumour suppressive role across many cancer types [66], and mutations or low expression of KMT2C are associated with poor survival in a wide range of lung, breast, gastric, skin and brain cancers [11, 17, 18, 33, 36, 41, 54, 63, 68, 73]. KMT2C was among the first few recurrently mutated genes identified in early medulloblastoma sequencing studies [53]. In our adult medulloblastoma cohort, KMT2C was one of the most frequently mutated genes, with mutations detected in $30 \%$ of cases across ages, sexes, histological types and molecular groups, so it is a potential biomarker for stratifying adult medulloblastoma patients. Our findings reaffirm the central importance of chromatin modification in medulloblastoma pathophysiology [26], and highlight the need for more comprehensive evaluation of the epigenetic landscape of adult medulloblastomas.

\section{Supplementary information}

Supplementary information accompanies this paper at https://doi. org/10.1186/s40478-020-01066-6.

Additional file 1. Supplementary Figures S1-S7

Additional file 2. Supplementary Tables S1-S6

\section{Acknowledgements}

This study was supported by the Children's Cancer Foundation, Hong Kong; the National Natural Science Foundation of China (Reference Nos. 81702465 , 81702471, U1904148, U1804172); the Shanghai Municipal Science and Technology Major Project (Reference No. 2018SHZDZX01); and Shanghai Brain Function Restoration and Neural Regeneration Key Laboratory.

\section{Author contributions \\ Study design: HKN, KKL Material preparation: HKN, WW, HC, ZZ, ZS, AKC Data collection: GCW, KKL, QJH, MFP, WW, APL Data analysis: GCW, QJH Data inter- pretation: GCW, HKN, KKL, AKC Manuscript preparation: GCW, KKL, WW Review and editing: HKN, KKL, AKC.}

\section{Competing interests}

The authors declare no conflict of interest.

\section{Author details}

${ }^{1}$ Department of Anatomical and Cellular Pathology, The Chinese University of Hong Kong, Shatin, Hong Kong. ${ }^{2}$ Department of Pathology, The First Affiliated Hospital of Zhengzhou University, Zhengzhou, China. ${ }^{3}$ Department of Paediatrics and Adolescent Medicine, The University of Hong Kong, Pok Fu Lam, Hong Kong. ${ }^{4}$ Department of Pathology, Huashan Hospital, Fudan University, Shanghai, China. ${ }^{5}$ Division of Neurosurgery, Department of Surgery, The Chinese University of Hong Kong, Shatin, Hong Kong. ${ }^{6}$ Department of Neurosurgery, The First Affiliated Hospital of Zhengzhou University, Zhengzhou, 
China. ${ }^{7}$ Department of Neurosurgery, Huashan Hospital, Fudan University, Shanghai, China.

Received: 10 October 2020 Accepted: 19 October 2020

Published online: 10 November 2020

\section{References}

1. Aibaidula A, Chan AK, Shi Z, Li Y, Zhang R, Yang R, Li KK, Chung NY, Yao Y, Zhou L, Wu J, Chen H, Ng HK (2017) Adult IDH wild-type lower-grade gliomas should be further stratified. Neuro Oncol 19:1327-1337. https:// doi.org/10.1093/neuonc/nox078

2. Al-Halabi H, Nantel A, Klekner A, Guiot M-C, Albrecht S, Hauser P, Garami M, Bognar L, Kavan P, Gerges N, Shirinian M, Roberge D, Muanza T, Jabado N (2011) Preponderance of sonic hedgehog pathway activation characterizes adult medulloblastoma. Acta Neuropathol 121:229-239. https:// doi.org/10.1007/s00401-010-0780-0

3. Ang C, Hauerstock D, Guiot M-C, Kasymjanova G, Roberge D, Kavan P, Muanza T (2008) Characteristics and outcomes of medulloblastoma in adults. Pediatr Blood Cancer 51:603-607. https://doi.org/10.1002/ pbc.21588

4. Brandes AA, Bartolotti M, Marucci G, Ghimenton C, Agati R, Fioravanti A, Mascarin M, Volpin L, Ammannati F, Masotto B, Gardiman MP, De Biase D, Tallini G, Crisi G, Bartolini S, Franceschi E (2015) New perspectives in the treatment of adult medulloblastoma in the era of molecular oncology. Crit Rev Oncol Hematol 94:348-359. https://doi.org/10.1016/j.critrevonc .2014 .12 .016

5. Brandes AA, Franceschi E (2014) Shedding light on adult medulloblastoma: current management and opportunities for advances. Am Soc Clin Oncol Edu Book 34:e82-e87. https://doi.org/10.14694/edboo k_am.2014.34.e82

6. Cavalli FMG, Remke M, Rampasek L, Peacock J, Shih DJH, Luu B, Garzia L, Torchia J, Nor C, Morrissy AS, Agnihotri S, Thompson YY, Kuzan-Fischer CM, Faroog H, Isaev K, Daniels C, Cho B-K, Kim S-K, Wang K-C, Lee JY, Grajkowska WA, Perek-Polnik M, Vasiljevic A, Faure-Conter C, Jouvet A, Giannini C, Nageswara Rao AA, Li KKW, Ng H-K, Eberhart CG, Pollack IF, Hamilton RL, Gillespie GY, Olson JM, Leary S, Weiss WA, Lach B, Chambless LB, Thompson RC, Cooper MK, Vibhakar R, Hauser P, Van Veelen M-LC, Kros JM, French PJ, Ra YS, Kumabe T, López-Aguilar E, Zitterbart K, Sterba J, Finocchiaro G, Massimino M, Van Meir EG, Osuka S, Shofuda T, Klekner A, Zollo M, Leonard JR, Rubin JB, Jabado N, Albrecht S, Mora J, Van Meter TE, Jung S, Moore AS, Hallahan AR, Chan JA, Tirapelli DPC, Carlotti CG, Fouladi M, Pimentel J, Faria CC, Saad AG, Massimi L, Liau LM, Wheeler H, Nakamura H, Elbabaa SK, Perezpeña-Diazconti M, De León FCP, Robinson S, Zapotocky M, Lassaletta A, Huang A, Hawkins CE, Tabori U, Bouffet E, Bartels U, Dirks PB, Rutka JT, Bader GD, Reimand J, Goldenberg A, Ramaswamy V, Taylor MD (2017) Intertumoral heterogeneity within medulloblastoma subgroups. Cancer Cell 31:737-754.e736. https://doi. org/10.1016/j.ccell.2017.05.005

7. Cerami E, Gao J, Dogrusoz U, Gross BE, Sumer SO, Aksoy BA, Jacobsen A, Byrne CJ, Heuer ML, Larsson E, Antipin Y, Reva B, Goldberg AP, Sander C, Schultz N (2012) The cBio cancer genomics portal: an open platform for exploring multidimensional cancer genomics data: figure 1. Cancer Discov 2:401-404. https://doi.org/10.1158/2159-8290.cd-12-0095

8. Chan AK-Y, Yao Y, Zhang Z, Chung NY-F, Liu JS-M, Li KK-W, Shi Z, Chan DT-M, Poon WS, Zhou L, Ng H-K (2015) TERT promoter mutations contribute to subset prognostication of lower-grade gliomas. Mod Pathol 28:177-186. https://doi.org/10.1038/modpathol.2014.94

9. Chan AK-Y, Yao Y, Zhang Z, Shi Z, Chen L, Chung NY-F, Liu JS-M, Li KK-W, Chan DT-M, Poon WS, Zhou L, Ng H-K (2015) Combination genetic signature stratifies lower-grade gliomas better than histological grade. Oncotarget 6:20885-20901. https://doi.org/10.18632/oncotarget.4928

10. Chan AW, Tarbell NJ, Black PM, Louis DN, Frosch MP, Ancukiewicz M, Chapman P, Loeffler JS (2000) Adult medulloblastoma: prognostic factors and patterns of relapse. Neurosurgery 47:623-632. https://doi. org/10.1097/00006123-200009000-00018

11. Cho S-J, Yoon C, Lee JH, Chang KK, Lin J-X, Kim Y-H, Kook M-C, Aksoy BA, Park DJ, Ashktorab H, Smoot DT, Schultz N, Yoon SS (2018) KMT2C mutations in diffuse-type gastric adenocarcinoma promote epithelial-to-mesenchymal transition. Clin Cancer Res 24:6556-6569. https://doi.org/10.1158/1078-0432.ccr-17-1679

12. Cosman R, Brown CSB, Debraganca KC, Khasraw M (2014) Patterns of care in adult medulloblastoma: results of an international online survey. J Neurooncol 120:125-129. https://doi.org/10.1007/s11060-014-1525-z

13. D'Arcy CE, Nobre LF, Arnaldo A, Ramaswamy V, Taylor MD, Naz-Hazrati L, Hawkins CE (2020) Immunohistochemical and nanostring-based subgrouping of clinical medulloblastoma samples. J Neuropathol Exp Neurol. https://doi.org/10.1093/jnen/nlaa005

14. Damalas A, Ben-Ze'Ev A, Simcha I, Shtutman M, Leal JF, Zhurinsky J, Geiger B, Oren M (1999) Excess beta-catenin promotes accumulation of transcriptionally active p53. EMBO J 18:3054-3063. https://doi.org/10.1093/ emboj/18.11.3054

15. Ellison DW, Dalton J, Kocak M, Nicholson SL, Fraga C, Neale G, Kenney AM, Brat DJ, Perry A, Yong WH, Taylor RE, Bailey S, Clifford SC, Gilbertson RJ (2011) Medulloblastoma: clinicopathological correlates of SHH, WNT, and non-SHH/WNT molecular subgroups. Acta Neuropathol 121:381-396. https://doi.org/10.1007/s00401-011-0800-8

16. Ellison DW, Kocak M, Dalton J, Megahed H, Lusher ME, Ryan SL, Zhao W, Nicholson SL, Taylor RE, Bailey S, Clifford SC (2011) Definition of diseaserisk stratification groups in childhood medulloblastoma using combined clinical, pathologic, and molecular variables. J Clin Oncol 29:1400-1407. https://doi.org/10.1200/jco.2010.30.2810

17. Fagan RJ, Dingwall AK (2019) COMPASS Ascending: emerging clues regarding the roles of MLL3/KMT2C and MLL2/KMT2D proteins in cancer. Cancer Lett 458:56-65. https://doi.org/10.1016/j.canlet.2019.05.024

18. Gala K, Li Q, Sinha A, Razavi P, Dorso M, Sanchez-Vega F, Chung YR, Hendrickson R, Hsieh JJ, Berger M, Schultz N, Pastore A, Abdel-Wahab O, Chandarlapaty S (2018) KMT2C mediates the estrogen dependence of breast cancer through regulation of ERa enhancer function. Oncogene 37:4692-4710. https://doi.org/10.1038/s41388-018-0273-5

19. Gao J, Aksoy BA, Dogrusoz U, Dresdner G, Gross B, Sumer SO, Sun Y, Jacobsen A, Sinha R, Larsson E, Cerami E, Sander C, Schultz N (2013) Integrative analysis of complex cancer genomics and clinical profiles using the cBioPortal. Sci Signal 6:pl1. https://doi.org/10.1126/scisignal.2004088

20. Gibson P, Tong Y, Robinson G, Thompson MC, Currle DS, Eden C, Kranenburg TA, Hogg T, Poppleton H, Martin J, Finkelstein D, Pounds S, Weiss A, Patay Z, Scoggins M, Ogg R, Pei Y, Yang Z-J, Brun S, Lee Y, Zindy F, Lindsey JC, Taketo MM, Boop FA, Sanford RA, Gajjar A, Clifford SC, Roussel MF, McKinnon PJ, Gutmann DH, Ellison DW, Wechsler-Reya R, Gilbertson RJ (2010) Subtypes of medulloblastoma have distinct developmental origins. Nature 468:1095-1099. https://doi.org/10.1038/nature09587

21. GoschzikT, Schwalbe EC, Hicks D, Smith A, Zur Muehlen A, FigarellaBranger D, Doz F, Rutkowski S, Lannering B, Pietsch T, Clifford SC (2018) Prognostic effect of whole chromosomal aberration signatures in standard-risk, non-WNT/non-SHH medulloblastoma: a retrospective, molecular analysis of the HIT-SIOP PNET 4 trial. Lancet Oncol 19:1602-1616. https:// doi.org/10.1016/s1470-2045(18)30532-1

22. Holgado BL, Guerreiro Stucklin A, Garzia L, Daniels C, Taylor MD (2017) Tailoring medulloblastoma treatment through genomics: making a change, one subgroup at a time. Annu Rev Genomics Hum Genet. https ://doi.org/10.1146/annurev-genom-091416-035434

23. Hovestadt V, Ayrault O, Swartling FJ, Robinson GW, Pfister SM, Northcott PA (2020) Medulloblastomics revisited: biological and clinical insights from thousands of patients. Nat Rev Cancer 20:42-56. https://doi. org/10.1038/s41568-019-0223-8

24. Hu D, Gao X, Morgan MA, Herz HM, Smith ER, Shilatifard A (2013) The MLL3/MLL4 branches of the COMPASS family function as major histone H3K4 monomethylases at enhancers. Mol Cell Biol 33:4745-4754. https:// doi.org/10.1128/mcb.01181-13

25. Iorgulescu JB, Van Ziffle J, Stevers M, Grenert JP, Bastian BC, Chavez L, Stichel D, Buchhalter I, Samuel D, Nicolaides T, Banerjee A, Mueller S, Gupta N, Tihan T, Bollen AW, Northcott PA, Kool M, Pfister S, Korshunov A, Perry A, Solomon DA (2018) Deep sequencing of WNT-activated medulloblastomas reveals secondary SHH pathway activation. Acta Neuropathol 135:635-638. https://doi.org/10.1007/s00401-018-1819-x

26. Jones DTW, Northcott PA, Kool M, Pfister SM (2013) The role of chromatin remodeling in medulloblastoma. Brain Pathol 23:193-199. https://doi. org/10.1111/bpa.12019

27. Kahn SA, Wang X, Nitta RT, Gholamin S, Theruvath J, Hutter G, Azad TD, Wadi L, Bolin S, Ramaswamy V, Esparza R, Liu K-W, Edwards M, Swartling 
FJ, Sahoo D, Li G, Wechsler-Reya RJ, Reimand J, Cho Y-J, Taylor MD, Weissman IL, Mitra SS, Cheshier SH (2018) Notch1 regulates the initiation of metastasis and self-renewal of Group 3 medulloblastoma. Nat Commun. https://doi.org/10.1038/s41467-018-06564-9

28. Koelsche C, Sahm F, Capper D, Reuss D, Sturm D, Jones DTW, Kool M, Northcott PA, Wiestler B, Böhmer K, Meyer J, Mawrin C, Hartmann C, Mittelbronn M, Platten M, Brokinkel B, Seiz M, Herold-Mende C, Unterberg A, Schittenhelm J, Weller M, Pfister S, Wick W, Korshunov A, Von Deimling A (2013) Distribution of TERT promoter mutations in pediatric and adult tumors of the nervous system. Acta Neuropathol 126:907-915. https:// doi.org/10.1007/s00401-013-1195-5

29. Kool M, David Jäger N, Paul Trevor, Hovestadt V, Rosario L, Shirley Remke M, Milde T, Bourdeaut F, Ryzhova M, Sturm D, Pfaff E, Stark S, Hutter S, Şeker-Cin H, Johann P, Bender S, Schmidt C, Rausch T, Shih D, Reimand J, Sieber L, Wittmann A, Linke L, Witt H, Ursula D, Zapatka M, König R, Beroukhim R, Bergthold G, Volckmann R, Slusis P, Koster J, Versteeg R, Schmidt S, Wolf S, Lawerenz C, Cynthia Christof, Unterberg A, HeroldMende C, Hofer S, Andreas Andreas, Scheurlen W, Felsberg J, Reifenberger G, Hasselblatt M, John Gerald, Jabado N, Perry A, Cowdrey C, Croul S, Zadeh G, Jan K, Doz F, Delattre O, Gary D, Martin G, Peter Collins V, Mark W, Cho Y-J, Scott L, Witt O, Brors B, Michael D, Schüller U, Korshunov A, Eils R, Robert J, Lichter P, Stefan M (2014) Genome sequencing of SHH medulloblastoma predicts genotype-related response to smoothened inhibition. Cancer Cell 25:393-405. https://doi.org/10.1016/j.ccr.2014.02.004

30. Kool M, Korshunov A, Remke M, Jones DTW, Schlanstein M, Northcott PA, Cho Y-J, Koster J, Schouten-Van Meeteren A, Van Vuurden D, Clifford SC, Pietsch T, Von Bueren AO, Rutkowski S, McCabe M, Collins VP, Bäcklund ML, Haberler C, Bourdeaut F, Delattre O, Doz F, Ellison DW, Gilbertson RJ, Pomeroy SL, Taylor MD, Lichter P, Pfister SM (2012) Molecular subgroups of medulloblastoma: an international meta-analysis of transcriptome, genetic aberrations, and clinical data of WNT, SHH, Group 3, and Group 4 medulloblastomas. Acta Neuropathol 123:473-484. https://doi. org/10.1007/s00401-012-0958-8

31. Korshunov A, Remke M, Werft W, Benner A, Ryzhova M, Witt H, Sturm D, Wittmann A, Schöttler A, Felsberg J, Reifenberger G, Rutkowski S, Scheurlen W, Kulozik AE, Von Deimling A, Lichter P, Pfister SM (2010) Adult and pediatric medulloblastomas are genetically distinct and require different algorithms for molecular risk stratification. J Clin Oncol 28:30543060. https://doi.org/10.1200/jco.2009.25.7121

32. Kumar R, Liu APY, Northcott PA (2020) Medulloblastoma genomics in the modern molecular era. Brain Pathol 30:679-690. https://doi.org/10.1111/ bpa. 12804

33. Lan Y, Zhao E, Luo S, Xiao Y, Li X, Cheng S (2019) Revealing clonality and subclonality of driver genes for clinical survival benefits in breast cancer. Breast Cancer Res Treat. https://doi.org/10.1007/s10549-019-05153-8

34. Lassaletta A, Ramaswamy V (2016) Medulloblastoma in adults: they're not just big kids. Neuro Oncol 18:895-897. https://doi.org/10.1093/neuonc/ now110

35. Levina E, Oren M, Ben-Ze'Ev A (2004) Downregulation of $\beta$-catenin by p53 involves changes in the rate of $\beta$-catenin phosphorylation and Axin dynamics. Oncogene 23:4444-4453. https://doi.org/10.1038/sj.onc.12075 87

36. Li B, Liu HY, Guo SH, Sun P, Gong FM, Jia BQ (2014) Association of MLL3 expression with prognosis in gastric cancer. Genet Mol Res 13:7513-7518. https://doi.org/10.4238/2014.september.12.18

37. Li Y-X, Shi Z, Aibaidula A, Chen H, Tang Q, Li KK-W, Chung NY-F, Chan DT-M, Poon WS, Mao Y, Wu J, Zhou L, Chan AK-Y, Ng H-K (2016) Not all 1p/19q non-codeleted oligodendroglial tumors are astrocytic. Oncotarget. https://doi.org/10.18632/oncotarget.11378

38. Lindsey JC, Schwalbe EC, Potluri S, Bailey S, Williamson D, Clifford SC (2014) TERT promoter mutation and aberrant hypermethylation are associated with elevated expression in medulloblastoma and characterise the majority of non-infant $\mathrm{SHH}$ subgroup tumours. Acta Neuropathol 127:307-309. https://doi.org/10.1007/s00401-013-1225-3

39. Louis DN, Perry A, Reifenberger G, Von Deimling A, Figarella-Branger D, Cavenee WK, Ohgaki H, Wiestler OD, Kleihues P, Ellison DW (2016) The 2016 world health organization classification of tumors of the central nervous system: a summary. Acta Neuropathol 131:803-820. https://doi. org/10.1007/s00401-016-1545-1
40. Majd N, Penas-Prado M (2019) Updates on management of adult medulIoblastoma. Curr Treat Options Oncol. https://doi.org/10.1007/s1186 4-019-0663-0

41. Manso L, Mourón S, Tress M, Gómez-López G, Morente M, Ciruelos E, Rubio-Camarillo M, Rodriguez-Peralto JL, Pujana MA, Pisano DG, QuintelaFandino M (2016) Analysis of paired primary-metastatic hormonereceptor positive breast tumors (HRPBC) uncovers potential novel drivers of hormonal resistance. PLOS ONE 11:e0155840. https://doi.org/10.1371/ journal.pone. 0155840

42. Menyhárt O, Giangaspero F, Győrffy B (2019) Molecular markers and potential therapeutic targets in non-WNT/non-SHH (group 3 and group 4) medulloblastomas. J Hematol Oncol 12:29. https://doi.org/10.1186/ s13045-019-0712-y

43. Morrissy AS, Cavalli FMG, Remke M, Ramaswamy V, Shih DJH, Holgado BL, Farooq H, Donovan LK, Garzia L, Agnihotri S, Kiehna EN, Mercier E, Mayoh C, Papillon-Cavanagh S, Nikbakht H, Gayden T, Torchia J, Picard D, Merino DM, Vladoiu M, Luu B, Wu X, Daniels C, Horswell S, Thompson YY, Hovestadt V, Northcott PA, Jones DTW, Peacock J, Wang X, Mack SC, Reimand J, Albrecht S, Fontebasso AM, Thiessen N, Li Y, Schein JE, Lee D, Carlsen R, Mayo M, Tse K, Tam A, Dhalla N, Ally A, Chuah E, Cheng Y, Plettner P, Li HI, Corbett RD, Wong T, Long W, Loukides J, Buczkowicz P, Hawkins CE, Tabori U, Rood BR, Myseros JS, Packer RJ, Korshunov A, Lichter P, Kool M, Pfister SM, Schüller U, Dirks P, Huang A, Bouffet E, Rutka JT, Bader GD, Swanton C, Ma Y, Moore RA, Mungall AJ, Majewski J, Jones SJM, Das S, Malkin D, Jabado N, Marra MA, Taylor MD (2017) Spatial heterogeneity in medulloblastoma. Nat Genet 49:780-788. https://doi. org/10.1038/ng.3838

44. Nobre L, Zapotocky M, Khan S, Fukuoka K, Fonseca A, McKeown T, Sumerauer D, Vicha A, Grajkowska WA, Trubicka J, Li KKW, Ng H-K, Massimi L, Lee JY, Kim S-K, Zelcer S, Vasiljevic A, Faure-Conter C, Hauser P, Lach B, Van Veelen-Vincent M-L, French PJ, Van Meir EG, Weiss WA, Gupta N, Pollack IF, Hamilton RL, Nageswara Rao AA, Giannini C, Rubin JB, Moore AS, Chambless LB, Vibhakar R, Ra YS, Massimino M, McLendon RE, Wheeler H, Zollo M, Ferruci V, Kumabe T, Faria CC, Sterba J, Jung S, López-Aguilar E, Mora J, Carlotti CG, Olson JM, Leary S, Cain J, Krskova L, Zamecnik J, Hawkins CE, Tabori U, Huang A, Bartels U, Northcott PA, Taylor MD, Yip S, Hansford JR, Bouffet E, Ramaswamy V (2020) Pattern of relapse and treatment response in WNT-activated medulloblastoma. Cell Rep Med 1:100038. https://doi.org/10.1016/j.xcrm.2020.100038

45. Northcott PA, Buchhalter I, Morrissy AS, Hovestadt V, Weischenfeldt J, Ehrenberger T, Gröbner S, Segura-Wang M, Zichner T, Rudneva VA, Warnatz $\mathrm{H}-\mathrm{J}$, Sidiropoulos N, Phillips AH, Schumacher S, Kleinheinz K, Waszak SM, Erkek S, Jones DTW, Worst BC, Kool M, Zapatka M, Jäger N, Chavez L, Hutter B, Bieg M, Paramasivam N, Heinold M, Gu Z, Ishaque N, JägerSchmidt C, Imbusch CD, Jugold A, Hübschmann D, Risch T, Amstislavskiy V, Gonzalez FGR, Weber UD, Wolf S, Robinson GW, Zhou X, Wu G, Finkelstein D, Liu Y, Cavalli FMG, Luu B, Ramaswamy V, Wu X, Koster J, Ryzhova M, Cho Y-J, Pomeroy SL, Herold-Mende C, Schuhmann M, Ebinger M, Liau LM, Mora J, McLendon RE, Jabado N, Kumabe T, Chuah E, Ma Y, Moore RA, Mungall AJ, Mungall KL, Thiessen N, Tse K, Wong T, Jones SJM, Witt O, Milde T, Von Deimling A, Capper D, Korshunov A, Yaspo M-L, Kriwacki R, Gajjar A, Zhang J, Beroukhim R, Fraenkel E, Korbel JO, Brors B, Schlesner M, Eils R, Marra MA, Pfister SM, Taylor MD, Lichter P (2017) The wholegenome landscape of medulloblastoma subtypes. Nature 547:311-317. https://doi.org/10.1038/nature22973

46. Northcott PA, Hielscher T, Dubuc A, Mack S, Shih D, Remke M, Al-Halabi H, Albrecht S, Jabado N, Eberhart CG, Grajkowska W, Weiss WA, Clifford SC, Bouffet E, Rutka JT, Korshunov A, Pfister S, Taylor MD (2011) Pediatric and adult sonic hedgehog medulloblastomas are clinically and molecularly distinct. Acta Neuropathol 122:231-240. https://doi.org/10.1007/s0040 1-011-0846-7

47. Northcott PA, Jones DTW, Kool M, Robinson GW, Gilbertson RJ, Cho Y-J, Pomeroy SL, Korshunov A, Lichter P, Taylor MD, Pfister SM (2012) Medulloblastomics: the end of the beginning. Nat Rev Cancer 12:818-834. https ://doi.org/10.1038/nrc3410

48. Northcott PA, Robinson GW, Kratz CP, Mabbott DJ, Pomeroy SL, Clifford SC, Rutkowski S, Ellison DW, Malkin D, Taylor MD, Gajjar A, Pfister SM (2019) Medulloblastoma. Nat Rev Dis Primers. https://doi.org/10.1038/ s41572-019-0063-6

49. Northcott PA, Shih DJH, Peacock J, Garzia L, Sorana Morrissy A, Zichner T, Stütz AM, Korshunov A, Reimand J, Schumacher SE, Beroukhim R, Ellison 
DW, Marshall CR, Lionel AC, Mack S, Dubuc A, Yao Y, Ramaswamy V, Luu B, Rolider A, Cavalli FMG, Wang X, Remke M, Wu X, Chiu RYB, Chu A, Chuah E, Corbett RD, Hoad GR, Jackman SD, Li Y, Lo A, Mungall KL, Ming Nip K, Qian JQ, Raymond AGJ, Thiessen N, Varhol RJ, Birol I, Moore RA, Mungall AJ, Holt R, Kawauchi D, Roussel MF, Kool M, Jones DTW, Witt H, Fernandez-L A, Kenney AM, Wechsler-Reya RJ, Dirks P, Aviv T, Grajkowska WA, Perek-Polnik M, Haberler CC, Delattre O, Reynaud SS, Doz FF, PernetFattet SS, Cho B-K, Kim S-K, Wang K-C, Scheurlen W, Eberhart CG, FèvreMontange M, Jouvet A, Pollack IF, Fan X, Muraszko KM, Yancey Gillespie G, Di Rocco C, Massimi L, Michiels EMC, Kloosterhof NK, French PJ, Kros $J M$, Olson JM, Ellenbogen RG, Zitterbart K, Kren L, Thompson RC, Cooper MK, Lach B, McLendon RE, Bigner DD, Fontebasso A, Albrecht S, Jabado N, Lindsey JC, Bailey S, Gupta N, Weiss WA, Bognár L, Klekner A, Van Meter TE, Kumabe T, Tominaga T, Elbabaa SK, Leonard JR, Rubin JB, Liau LM, Van Meir EG, Fouladi M, Nakamura H, Cinalli G, Garami M, Hauser P, Saad AG, Iolascon A, Jung S, Carlotti CG, Vibhakar R, Shin Ra Y, Robinson S, Zollo M, Faria CC, Chan JA, Levy ML, Sorensen PHB, Meyerson M, Pomeroy SL, Cho Y-J, Bader GD, Tabori U, Hawkins CE, Bouffet E, Scherer SW, Rutka JT, Malkin D, Clifford SC, Jones SJM, Korbel JO, Pfister SM, Marra MA, Taylor MD (2012) Subgroup-specific structural variation across 1,000 medulloblastoma genomes. Nature 488:49-56. https://doi.org/10.1038/natur e11327

50. Northcott PA, Shih DJH, Remke M, Cho Y-J, Kool M, Hawkins C, Eberhart CG, Dubuc A, Guettouche T, Cardentey Y, Bouffet E, Pomeroy SL, Marra M, Malkin D, Rutka JT, Korshunov A, Pfister S, Taylor MD (2012) Rapid, reliable, and reproducible molecular sub-grouping of clinical medulloblastoma samples. Acta Neuropathol 123:615-626. https://doi.org/10.1007/s0040 1-011-0899-7

51. Orr BA (2020) Pathology, diagnostics, and classification of medulloblastoma. Brain Pathol 30:664-678. https://doi.org/10.1111/bpa.12837

52. Ostrom QT, Cioffi G, Gittleman H, Patil N, Waite K, Kruchko C, BarnholtzSloan JS (2019) CBTRUS statistical report: primary brain and other central nervous system tumors diagnosed in the United States in 2012-2016. Neuro Oncol 21:v1-v100. https://doi.org/10.1093/neuonc/noz150

53. Parsons DW, Li M, Zhang X, Jones S, Leary RJ, Lin JCH, Boca SM, Carter H, Samayoa J, Bettegowda C, Gallia GL, Jallo GI, Binder ZA, Nikolsky Y, Hartigan J, Smith DR, Gerhard DS, Fults DW, Vandenberg S, Berger MS, Marie SKN, Shinjo SMO, Clara C, Phillips PC, Minturn JE, Biegel JA, Judkins AR, Resnick AC, Storm PB, Curran T, He Y, Rasheed BA, Friedman HS, Keir ST, McLendon R, Northcott PA, Taylor MD, Burger PC, Riggins GJ, Karchin R, Parmigiani G, Bigner DD, Yan H, Papadopoulos N, Vogelstein B, Kinzler KW, Velculescu VE (2011) The genetic landscape of the childhood cancer medulloblastoma. Science 331:435-439. https://doi.org/10.1126/scien ce.1198056

54. Pickering CR, Zhou JH, Lee JJ, Drummond JA, Peng SA, Saade RE, Tsai KY, Curry JL, Tetzlaff MT, Lai SY, Yu J, Muzny DM, Doddapaneni H, Shinbrot E, Covington KR, Zhang J, Seth S, Caulin C, Clayman GL, El-Naggar AK, Gibbs RA, Weber RS, Myers JN, Wheeler DA, Frederick MJ (2014) Mutational landscape of aggressive cutaneous squamous cell carcinoma. Clin Cancer Res 20:6582-6592. https://doi.org/10.1158/1078-0432.ccr-14-1768

55. Ramaswamy V, Remke M, Bouffet E, Bailey S, Clifford SC, Doz F, Kool M, Dufour C, Vassal G, Milde T, Witt O, Von Hoff K, Pietsch T, Northcott PA, Gajjar A, Robinson GW, Padovani L, André N, Massimino M, Pizer B, Packer R, Rutkowski S, Pfister SM, Taylor MD, Pomeroy SL (2016) Risk stratification of childhood medulloblastoma in the molecular era: the current consensus. Acta Neuropathol 131:821-831. https://doi.org/10.1007/s0040 1-016-1569-6

56. Ramaswamy V, Taylor MD (2017) Medulloblastoma: from Myth to Molecular. J Clin Oncol 35:2355-2363. https://doi.org/10.1200/jco.2017.72.7842

57. Reinecke F, Satya RV, Dicarlo J (2015) Quantitative analysis of differences in copy numbers using read depth obtained from PCR-enriched samples and controls. BMC Bioinform. https://doi.org/10.1186/s12859-014-0428-5

58. Remke M, Hielscher T, Northcott PA, Witt H, Ryzhova M, Wittmann A, Benner A, Von Deimling A, Scheurlen W, Perry A, Croul S, Kulozik AE, Lichter P, Taylor MD, Pfister SM, Korshunov A (2011) Adult medulloblastoma comprises three major molecular variants. J Clin Oncol 29:2717-2723. https://doi.org/10.1200/jco.2011.34.9373

59. Remke M, Ramaswamy V, Peacock J, Shih DJH, Koelsche C, Northcott PA, Hill N, Cavalli FMG, Kool M, Wang X, Mack SC, Barszczyk M, Morrissy AS, Wu X, Agnihotri S, Luu B, Jones DTW, Garzia L, Dubuc AM, Zhukova N, Vanner R, Kros JM, French PJ, Van Meir EG, Vibhakar R, Zitterbart
K, Chan JA, Bognár L, Klekner A, Lach B, Jung S, Saad AG, Liau LM, Albrecht S, Zollo M, Cooper MK, Thompson RC, Delattre OO, Bourdeaut F, Doz FF, Garami M, Hauser P, Carlotti CG, Van Meter TE, Massimi L, Fults D, Pomeroy SL, Kumabe T, Ra YS, Leonard JR, Elbabaa SK, Mora J, Rubin JB, Cho Y-J, McLendon RE, Bigner DD, Eberhart CG, Fouladi M, WechslerReya RJ, Faria CC, Croul SE, Huang A, Bouffet E, Hawkins CE, Dirks PB, Weiss WA, Schüller U, Pollack IF, Rutkowski S, Meyronet D, Jouvet A, Fèvre-Montange M, Jabado N, Perek-Polnik M, Grajkowska WA, Kim S-K, Rutka JT, Malkin D, Tabori U, Pfister SM, Korshunov A, Von Deimling A, Taylor MD (2013) TERT promoter mutations are highly recurrent in SHH subgroup medulloblastoma. Acta Neuropathol 126:917-929. https:// doi.org/10.1007/s00401-013-1198-2

60. Robinson GW, Orr BA, Wu G, Gururangan S, Lin T, Qaddoumi I, Packer RJ, Goldman S, Prados MD, Desjardins A, Chintagumpala M, Takebe N, Kaste SC, Rusch M, Allen SJ, Onar-Thomas A, Stewart CF, Fouladi M, Boyett JM, Gilbertson RJ, Curran T, Ellison DW, Gajjar A (2015) Vismodegib exerts targeted efficacy against recurrent sonic hedgehog-subgroup medulloblastoma: results from phase II pediatric brain tumor consortium studies PBTC-025B and PBTC-032. J Clin Oncol 33:2646-2654. https://doi.org/10.1200/jco.2014.60.1591

61. Ryan SL, Schwalbe EC, Cole M, Lu Y, Lusher ME, Megahed H, O'Toole K, Nicholson SL, Bognar L, Garami M, Hauser P, Korshunov A, Pfister SM, Williamson D, Taylor RE, Ellison DW, Bailey S, Clifford SC (2012) MYC family amplification and clinical risk-factors interact to predict an extremely poor prognosis in childhood medulloblastoma. Acta Neuropathol 123:501-513. https://doi.org/10.1007/s0040 1-011-0923-y

62. Sadot E, Geiger B, Oren M, Ben-Ze'Ev A (2001) Down-regulation of b-catenin by activated p53. Mol Cell Biol 21:6768-6781. https://doi. org/10.1128/mcb.21.20.6768-6781.2001

63. Sato K, Akimoto K (2016) Expression levels of KMT2C and SLC20A1 identified by information-theoretical analysis are powerful prognostic biomarkers in estrogen receptor-positive breast cancer. Clin Breast Cancer. https://doi.org/10.1016/j.clbc.2016.11.005

64. Shi Z-F, Li KK-W, Kwan JSH, Yang RR, Aibaidula A, Tang Q, Bao Y, Mao Y, Chen $\mathrm{H}, \mathrm{Ng} \mathrm{H}-\mathrm{K}$ (2019) Whole exome sequencing revealed mutational profiles of giant cell glioblastomas. Brain Pathol. https://doi. org/10.1111/bpa.12720

65. Shih DJH, Northcott PA, Remke M, Korshunov A, Ramaswamy V, Kool M, Luu B, Yao Y, Wang X, Dubuc AM, Garzia L, Peacock J, Mack SC, Wu X, Rolider A, Morrissy AS, Cavalli FMG, Jones DTW, Zitterbart K, Faria CC, Schuller U, Kren L, Kumabe T, Tominaga T, Shin Ra Y, Garami M, Hauser P, Chan JA, Robinson S, Bognar L, Klekner A, Saad AG, Liau LM, Albrecht S, Fontebasso A, Cinalli G, De Antonellis P, Zollo M, Cooper MK, Thompson RC, Bailey S, Lindsey JC, Di Rocco C, Massimi L, Michiels EMC, Scherer SW, Phillips JJ, Gupta N, Fan X, Muraszko KM, Vibhakar R, Eberhart CG, Fouladi M, Lach B, Jung S, WechslerReya RJ, Fevre-Montange M, Jouvet A, Jabado N, Pollack IF, Weiss WA, Lee JY, Cho BK, Kim SK, Wang KC, Leonard JR, Rubin JB, De Torres C, Lavarino C, Mora J, Cho YJ, Tabori U, Olson JM, Gajjar A, Packer RJ, Rutkowski S, Pomeroy SL, French PJ, Kloosterhof NK, Kros JM, Van Meir EG, Clifford SC, Bourdeaut F, Delattre O, Doz FF, Hawkins CE, Malkin D, Grajkowska WA, Perek-Polnik M, Bouffet E, Rutka JT, Pfister SM, Taylor MD (2014) Cytogenetic prognostication within medulloblastoma subgroups. J Clin Oncol 32:886-896. https://doi. org/10.1200/jco.2013.50.9539

66. Sze CC, Shilatifard A (2016) MLL3/MLL4/COMPASS family on epigenetic regulation of enhancer function and cancer. Cold Spring Harb Perspect Med 6:a026427. https://doi.org/10.1101/cshperspect.a026427

67. Taylor MD, Northcott PA, Korshunov A, Remke M, Cho Y-J, Clifford SC, Eberhart CG, Parsons DW, Rutkowski S, Gajjar A, Ellison DW, Lichter P, Gilbertson RJ, Pomeroy SL, Kool M, Pfister SM (2012) Molecular subgroups of medulloblastoma: the current consensus. Acta Neuropathol 123:465-472. https://doi.org/10.1007/s00401-011-0922-z

68. Wang L, Zhao Z, Ozark PA, Fantini D, Marshall SA, Rendleman EJ, Cozzolino KA, Louis N, He X, Morgan MA, Takahashi Y-H, Collings CK, Smith ER, Ntziachristos P, Savas JN, Zou L, Hashizume R, Meeks JJ, Shilatifard A (2018) Resetting the epigenetic balance of Polycomb and COMPASS function at enhancers for cancer therapy. Nat Med 24:758-769. https:// doi.org/10.1038/s41591-018-0034-6 
69. Xu C, Gu X, Padmanabhan R, Wu Z, Peng Q, Dicarlo J, Wang Y (2018) smCounter2: an accurate low-frequency variant caller for targeted sequencing data with unique molecular identifiers. Bioinformatics. https://doi.org/10.1093/bioinformatics/bty790

70. Yang H, Wang K (2015) Genomic variant annotation and prioritization with ANNOVAR and wANNOVAR. Nat Protoc 10:1556-1566. https://doi. org/10.1038/nprot.2015.105

71. Yang RR, Aibaidula A, Wang W-W, Chan AK-Y, Shi Z-F, Zhang Z-Y, Chan DTM, Poon WS, Liu X-Z, Li W-C, Zhang R-Q, Li Y-X, Chung NY-F, Chen H, Wu J, Zhou L, Li KK-W, Ng H-K (2018) Pediatric low-grade gliomas can be molecularly stratified for risk. Acta Neuropathol 136:641-655. https://doi. org/10.1007/s00401-018-1874-3

72. Yang RR, Shi ZF, Zhang ZY, Chan AKY, Aibaidula A, Wang WW, Kwan JSH, Poon WS, Chen H, Li WC, Chung NYF, Punchhi G, Chu WCY, Chan ISH, Liu XZ, Mao Y, Li KKW, Ng HK (2020) IDH mutant lower grade (WHO Grades II/III) astrocytomas can be stratified for risk by CDKN2A, CDK4 and PDGFRA copy number alterations. Brain Pathol 30:541-553. https://doi. org/10.1111/bpa.12801

73. Zhang L, Liu Y, Wang M, Wu Z, Li N, Zhang J, Yang C (2017) EZH2-, CHD4-, and IDH-linked epigenetic perturbation and its association with survival in glioma patients. J Mol Cell Biol 9:477-488. https://doi.org/10.1093/ $\mathrm{jmcb} / \mathrm{mj} \times 056$
74. Zhao F, Ohgaki H, Xu L, Giangaspero F, Li C, Li P, Yang Z, Wang B, Wang X Wang Z, Ai L, Zhang J, Luo L, Liu P (2016) Molecular subgroups of adult medulloblastoma: a long-term single-institution study. Neuro Oncol 18:982-990. https://doi.org/10.1093/neuonc/now050

75. Zhukova N, Ramaswamy V, Remke M, Pfaff E, Shih DJH, Martin DC, Castelo-Branco P, Baskin B, Ray PN, Bouffet E, Von Bueren AO, Jones DTW, Northcott PA, Kool M, Sturm D, Pugh TJ, Pomeroy SL, Cho Y-J, Pietsch T, Gessi M, Rutkowski S, Bognar L, Klekner A, Cho B-K, Kim S-K, Wang K-C, Eberhart CG, Fevre-Montange M, Fouladi M, French PJ, Kros M, Grajkowska WA, Gupta N, Weiss WA, Hauser P, Jabado N, Jouvet A, Jung S, Kumabe T, Lach B, Leonard JR, Rubin JB, Liau LM, Massimi L, Pollack IF, Shin Ra Y, Van Meir EG, Zitterbart K, Schüller U, Hill RM, Lindsey JC, Schwalbe EC, Bailey S, Ellison DW, Hawkins C, Malkin D, Clifford SC, Korshunov A, Pfister S, Taylor MD, Tabori U (2013) Subgroup-specific prognostic implications of TP53 mutation in medulloblastoma. J Clin Oncol 31:2927-2935. https://doi.org/10.1200/jco.2012.48.5052

\section{Publisher's Note}

Springer Nature remains neutral with regard to jurisdictional claims in published maps and institutional affiliations.
Ready to submit your research? Choose BMC and benefit from:

- fast, convenient online submission

- thorough peer review by experienced researchers in your field

- rapid publication on acceptance

- support for research data, including large and complex data types

- gold Open Access which fosters wider collaboration and increased citations

- maximum visibility for your research: over $100 \mathrm{M}$ website views per year

At BMC, research is always in progress.

Learn more biomedcentral.com/submissions 